\title{
ROBOTIC CHOLECYSTECTOMY USING SENHANCE PLATFORM IN KLAIPEDA UNIVERSITY HOSPITAL
}

\author{
Vitalijus Eismontas ${ }^{1,3}$, Olegas Deduchovas ${ }^{1}$, Narimantas Evaldas Samalavičius ${ }^{1,2,3}$, \\ Arvydas Martinkẻnas ${ }^{3}$, Vinsas Janušonis ${ }^{1,3}$ \\ ${ }^{1}$ Department of Surgery, Klaipeda University Hospital, Klaipeda, Lithuania, \\ ${ }^{2}$ Institute of Clinical Medicine, Faculty of Medicine, Vilnius University, Vilnius, Lithuania, \\ ${ }^{3}$ Health Research and Innovation Science Center, Faculty of Health Sciences, \\ Klaipeda University, Klaipeda, Lithuania
}

Keywords: robotic surgery, robotic cholecystectomy, cholecystectomy.

\begin{abstract}
Summary
In this retrospective study we report the first experience of robotic cholecystectomies in Baltic countries. From Nov 2018 to Mar 2021, 72 robotic cholecystectomies were performed in Klaipeda University Hospital using the Senhance (TransEnterix) robotic system. Patients were diagnosed with symptomatic gallstone disease and had no life-threatening co-morbidities. We retrospectively investigated patient demographics and pre-, peri- and postoperative data. Eighteen male and fifty four female patients were included in this study $(\mathrm{n}=72)$. Mean age was 53 years (range 21-85); mean BMI was $26.6 \mathrm{~kg} /$ $\mathrm{m}^{2}$ (range 21.1-43.7). Mean docking time was $10 \mathrm{~min}$ (range 1-55), and mean operative time was 80 min (range 50-138). There were no conversions to standard laparoscopy or open surgery. There were no intra-operative complications. There was one post-operative bleeding from the gallbladder bed and subhepatic hematoma, successfully treated by laparoscopy. This study demonstrates the feasibility of robotic surgery in performing minimally invasive cholecystectomies.
\end{abstract}

\section{Introduction}

In 1882, Carl Langebuch (1846-1901) of Germany performed the first cholecystectomy [1]. In 1985 (103 years later), Erich Mühe of Germany performed the first laparoscopic cholecystectomy, following by Phillipe Mouret (1987). Because of its advantages (smaller incisions, quicker recovery time, improved cosmetic results and shorter hospital stay), became accepted within a few years as the new standard therapy for gallstone disease [1]. The first robotic-assisted cholecystectomy was performed in 1997 and since then many reports on robotic cholecystectomy have been published [2]. All authors agreed on the safety and feasibility of the robotic procedure. However, most of them concluded that this procedure is not acceptable as a standard operation because of the lack of benefits for patients due to the high cost and prolonged operating time. In this regard, the benefits of the robotic procedure in gallbladder diseases have not yet been established [3-4]. However, until recently, robotic-assisted surgery has exclusively been connected to the name DaVinci ${ }^{\circledR}$. In 2016, a second robotic system, the Senhance ${ }^{\circledR}$, became available [5]. Because of its safety and possibility to resterilize the instruments of Senhance robotic system, it became feasible to perform smaller routine operations like robotic cholecystectomy [6].

\section{Materials and methods}

From November 2018 to March 2021, a total of 72 robotic cholecystectomies were performed at Klaipeda University Hospital. We prospectively collected the docking time and console time in all robotic procedures. The initial indications of surgery included symptomatic gallstones. Exclusion criteria were the presence of acute cholecystitis and previous history of extensive upper abdominal surgery. Informed consent was obtained for the robotic cholecystectomy. We retrospectively reviewed the medical records of all patients and analyzed data, including demographic information, clinical presentation, results of laboratory studies, operative records, postoperative complications, and postoperative hospital stay.

In this study, the operating time was defined as the time from skin incision to wound closure. The docking time spanned the setup of the robot onto the surgical field. The console 
time was defined as the time from the start of dissection until the moment the gallbladder was completely freed from the liver.

The robotic-assisted operations were performed with the Senhance system (TransEnterix, Inc., Morrisville, NC, USA). We participated in a 4-day intensive training program with this system at the European training center of TransEnterix Inc. in Milan. Surgeons and nurses of our team were able to use the robot over several hours. The training was concluded with procedural performances in an animal model, a test, and a certificate being awarded. The operating team consisted of one operating surgeon, one assisting surgeon and the certified nurse. The assisting surgeon replaced instruments and paced clips during cholecystectomy. Robotic cholecystectomy was performed using a four port technique (Figure 1). First, a $10-\mathrm{mm}$ trocar was inserted through an incision over the umbilicus using a close method. $\mathrm{CO} 2$ gas was introduced through this trocar to obtain an intraperitoneal pressure of $12 \mathrm{~mm} \mathrm{Hg}$. All other ports were placed under direct visualization. The 10 and $5 \mathrm{~mm}$ ports were placed about $8-10 \mathrm{~cm}$ on the right and on the left from the umbilicus, respectively. An additional fourth trocar $(5 \mathrm{~mm})$ was placed in the right anterior axillary line in the upper quadrant and used for retraction and suction by assistant.

The patient was then placed in reverse Trendelenburg position with the right side up. The Senhance TransEnterix

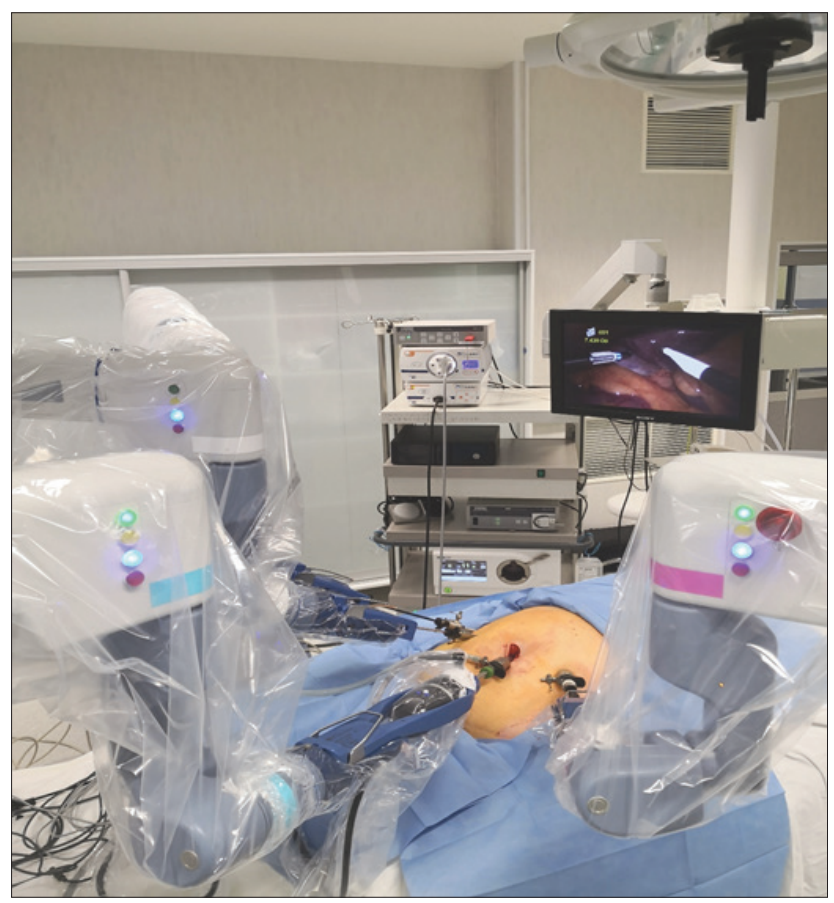

Figure 1. Docking of robotic arms surgical robot was then brought into position and docked. When performing cholecystectomy with the Senhance, TransEnterix robotic system, 3 independently usable robotic arms are used (Figure 1). To prepare, we regularly use a monopolar hook (right hand/right robotic arm) and a bipolar grasper (left hand/left robotic arm) (Figure 2). The third arm is used as a camera holder. An integrated 3D camera with 16-fold magnification offers a very high-quality visible field and precise assessment of thinnest tissue structures. With 'Eye-Sensing Control', the camera can be maneuvered precisely by the eye movements of the surgeon after the initial calibration from the console (Figure 3). The dissection was performed according to the standard laparoscopic technique. After clear identification of the cystic duct and cystic artery, the cystic duct was ligated manually with clips. The cystic artery was coagulated or clipped just around the gallbladder. The gallbladder was dissected from the bed. Once fully dissected, the gallbladder was removed through the umbilical $18 \mathrm{~mm}$ port. The robot was then withdrawn, and the $18 \mathrm{~mm}$ port

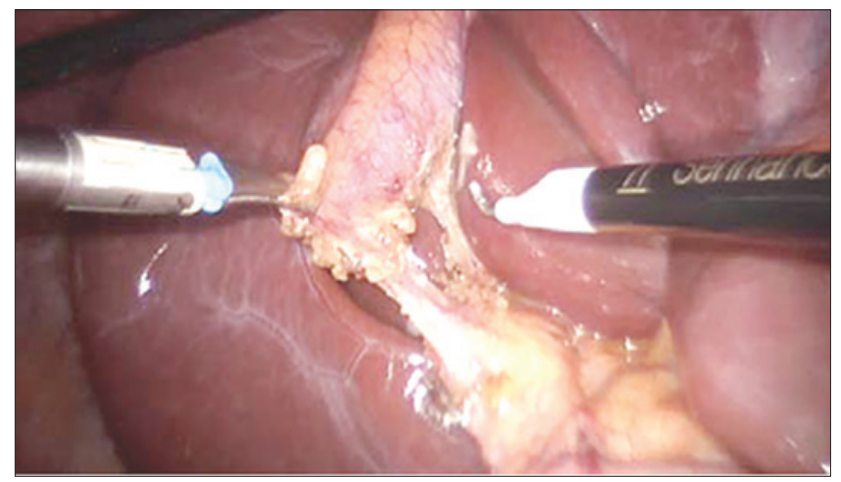

Figure 2. Robotic dissection in process

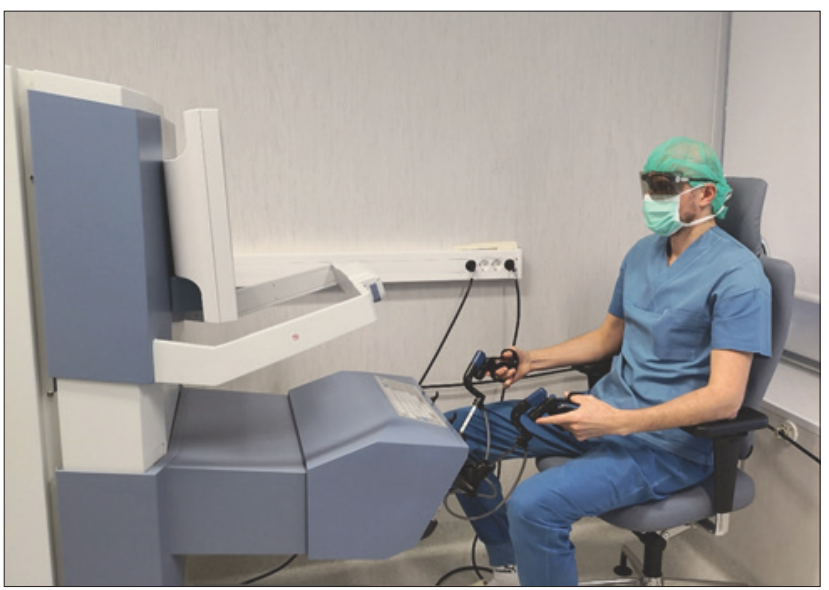

Figure 3. Surgeon works at console 
site was closed with absorbable sutures. Finally, the skin incisions at the port sites were sutured.

Patients were discharged on the first or second day after surgery if sufficiently recovered and if pain and nausea had receded. All patients were seen for examination and reassessment at the outpatient clinics 1 week after surgery. Laboratory tests were performed only if indicated.

Eighteen patients were male and 54 female; the age ranged from 21 to 85 years of age (mean 53). Table 1 shows the clinical characteristics of patients who underwent robotic cholecystectomy. The associated diseases were hypertension $(n=28)$, diabetes mellitus $(n=2)$. The previous operations were appendectomy $(n=5)$, hysterectomy $(n=2)$, prostatectomy $(\mathrm{n}=1)$, nephrectomy $(\mathrm{n}=1)$, mastectomy $(\mathrm{n}=3)$, thyroidectomy $(n=1)$. Endoscopic retrograde cholangiopancreatogram (ERCP) and biliary stones extraction were performed in 7 of 72 patients $(10 \%)$ in the period from one week to two months before surgery. After robotic cholecystectomy, all patients were diagnosed with gallbladder stones.

\section{Results}

All robotic procedures were successfully completed. The mean operation time was $80 \pm 15.1 \mathrm{~min}$. The docking time and console time were $10 \pm 6 \mathrm{~min}(1-55 \mathrm{~min})$ and $48 \pm 15.0 \mathrm{~min}$ (27-110 $\mathrm{min}$ ), respectively (Table 2 ). The conversion rate to laparoscopic or open procedures was zero. The complication rates was $1.4 \%(\mathrm{n}=1$, bleeding and postoperative hematoma $)$ (Table 3). The patient who had complication was a 58-yearold man who was discharged on the first post operative day, but was readmitted and underwent re-laparoscopy on postoperative day 4; previous incisions on the low abdominal area were employed during the surgery. We identified the focus of bleeding on the gallbladder bed and coagulated the bleeder. The patient was finally discharged from the hospital without any symptoms. There was no bleeding associated with the cystic artery. There was no bile duct injury and mortality. The mean postoperative hospital stay was $1.6 \pm 1.1 \mathrm{~d}$.

\section{Discussion}

The worldwide number and interest of robotic-assisted surgeries is growing in the recent past years. In abdominal surgery, robotic-assisted surgery has so far only been used in selected complex cases, mostly because of the high costs and the comparably long process times. In a prospective case-matched study Breinstein et al. [7] concluded that, while $\mathrm{RC}$ was safe and valuable, they were unable to justify its use because of the high cost of the robotic system. The authors found no added benefits to the patients versus laparoscopic cholecystectomy (LC). Heemskerk et al., in 2005 reported similar findings in a series of 24 patients [7]. A significantly
Table 1. Demographic data

\begin{tabular}{|l|}
\hline \multicolumn{1}{|c|}{ Robotic cholecystectomy $(\mathbf{n}=\mathbf{7 2})$} \\
\hline Age 53 (range $21-85)$ \\
\hline Gender (male/female) $18 / 54$ \\
\hline Previous ERCP and bile stones extraction $7 / 72(10 \%)$ \\
\hline BMI $26.6 \mathrm{~kg} / \mathrm{m} 2$ (range $21.1-42.7)$ \\
\hline White blood cell count $5.9(2.05-9.5)$ \\
\hline Diabetes mellitus 2 \\
\hline Hypertension 28 \\
\hline Bronchial asthma 3 \\
\hline Pancreatitis 2 \\
\hline Depression 1 \\
\hline Parkinson`s disease 1 \\
\hline
\end{tabular}

Table 2. Operation details

\begin{tabular}{|ll|}
\hline Operation time $(\mathrm{min})$ & $80($ range $50-138)$ \\
\hline Docking time $(\mathrm{min})$ & $10($ range $1-55)$ \\
\hline Console time $(\mathrm{min})$ & $48($ range $27-110)$ \\
\hline
\end{tabular}

Table 3. Surgical outcomes of robotic cholecystectomy

\begin{tabular}{|l|c|}
\hline Postoperative bleeding & 1 \\
\hline Bile duct injury & 0 \\
\hline Laparoscopic conversion & 0 \\
\hline Open conversion & 0 \\
\hline Total hospital stay (d) & $2.1 \pm 1.2$ \\
\hline Postoperative hospital stay (d) & $1.6 \pm 1.1$ \\
\hline
\end{tabular}

longer operative time than LC with no advantage from robotic assistance were reported previously $[4,8]$. However, Zhou et al., in their series of 40 patients, found that robotic assistance provided better control of the operative field and had the advantage of increased precision and stability when compared with LC [9]. The introduction of a Senhance TransEnterix robotic system has created new feasibility for robotic cholecystectomy, because of the safety and reduced per-case costs [5-6]. Especially with a high case load, this reduction is significant. All instruments of this robotic platform are resterilizable and standard trocars are used. Therefore, especially during the learning curve, it became feasible to perform smaller routine operations like RC.

In our study we have experienced one complication, postoperative bleeding (1.4\%). The reported incidence of bleeding in laparoscopic cholecystectomy can be up to $2 \%$ (reported range, $0.03 \%$ to $10 \%$ ). Despite of the high rate of postoperative bleeding in our study, we strongly believe that with the expanding of RC patient number, the rate of the latter complication will become acceptable.

We also have experienced the benefits for surgeons in the area of ergonomic during operation including a comfor- 
table and relaxed seating position (Figure 3). In traditional laparoscopy, the operating surgeon is dependent on the experience of the assistant and his/her camera steering. In this context, a special advantage of robotic-assisted surgery may be comfortable ergonomics, a 3-dimensional (3D) view of the operating field, up to 16 -fold magnification, and stable camera positioning which automatically compensates for unwanted camera movements. Further studies need to be performed to verify advantages and disadvantages of the robotic cholecystectomy compared to laparoscopic surgery.

\section{References}

1. Reynolds W Jr. The First Laparoscopic Cholecystectomy. JSLS 2001; 5(1): 89-94.

2. Solano C, Gualtierotti M, Cahill R, Marescaux J. Robot-assisted Cholecystectomy. Biliary Lithiasis 2008;209-216.

https://doi.org/10.1007/978-88-470-0763-5_17

3. Strosberg DS, Nguyen MC, Muscarella P, Narula VK. A retrospective comparison of robotic cholecystectomy versus laparoscopic cholecystectomy: operative outcomes and cost analysis. Surgical Endoscopy 2016;31: 304-307.

https://doi.org/10.1007/s00464-016-5134-0

4. Nio D, Bemelman WA, Busch OR, Vrouenraets BC, Gouma DJ. Robot-assisted laparoscopic cholecystectomy versus conventional laparoscopic cholecystectomy: a comparative study. Surg Endosc 2004;18:379-382. https://doi.org/10.1007/s00464-003-9133-6

5. Stephan D, Sälzer H, Willeke F. First Experiences with the New Senhance ${ }^{\circledR}$ Telerobotic System in Visceral Surgery. Visc Med 2018; 34(1):31-36. https://doi.org/10.1159/000486111

6. Melling N, Barr J, Schmitz R, Polonski A, Miro J, Ghadban T, Wodack K, Izbicki J, Zani S, Perez D. Robotic cholecystectomy: first experience with the new Senhance robotic system. J Robot Surg 2018;701-704.

https://doi.org/10.1007/s11701-018-0877-3

7. Breitenstein S, Nocito A, Puhan M, Held U, Weber M, Clavien PA. Robotic-assisted versus laparoscopic cholecystectomy: outcome and cost analyses of a case-matched control study. Ann Surg 2008; 247: 987-9 93.

https://doi.org/10.1097/SLA.0b013e318172501f
8. Kornprat P, Werkgartner G, Cerwenka H, Bacher H, El-Shabrawi A, Rehak P. Prospective study comparing standard and robotically assisted laparoscopic cholecystectomy. Langenbecks Arch Surg 2006;391:216-221.

https://doi.org/10.1007/s00423-006-0046-4

9. Zhou HX, Guo YH, Yu XF, Bao SY, Liu JL, Zhang Y. Zeus robot-assisted laparoscopic cholecystectomy in comparison with conventional laparoscopic cholecystectomy. Hepatobiliary Pancreat Dis Int 2006; 5: 115-118.

10. Kaushik R. Bleeding complications in laparoscopic cholecystectomy: Incidence, mechanisms, prevention and management. Journal of Minimal Access Surgery 2010; 6: 59-65.

https://doi.org/10.4103/0972-9941.68579

\section{ROBOTINĖ CHOLECISTEKTOMIJA, NAUDOJANT SENHANCE TRANSENTERIX ROBOTINE SISTEMA KLAIPE்DOS UNIVERSITETINĖJE LIGONINĖJE V. Eismontas, O. Deduchovas, N.E. Samalavičius, \\ A. Martinkẻnas, V. Janušonis}

Raktažodžiai: robotinè chirurgija, robotinè cholecistektomija, cholecistektomija.

Santrauka

Šiame retrospektyviniame tyrime pateikta pirmoji patirtis atliekant robotines cholecistektomijas Baltijos šalyse.

Nuo 2018 m. lapkričio mèn. iki 2021 m. kovo mèn. Klaipèdos universitetinejje ligonineje buvo atliktos 72 robotinès cholecistektomijos naudojant Senhance TransEnterix robotinę sistemą. İtraukti pacientai, sergantys tulžies pūslès akmenlige. Atlikta retrospektyvi priešoperacinių, operacinių ir pooperacinių duomenų analizè. Tyrime dalyvavo 18 vyrų ir 54 moterys. Amžiaus vidurkis buvo 53 metai. BMI vidurkis buvo $26.6 \mathrm{~kg} / \mathrm{m}^{2}$. Vidutine operacijos trukmè buvo $80 \mathrm{~min}$. Visos operacijos pradetos ir baigtos robotiniu metodu. Mes neturèjome intraoperacinių komplikacijų. Nustatème vieną pooperacinę komplikaciją - kraujavimą ir tulžies pūslès guolio srities hematomą. Komplikacija sèkmingai išgydyta laparoskopiniu metodu.

Robotine cholecistektomija yra inovatyvus ir saugus gydymo būdas gydant tulžies pūslès akmenligę.

Adresas susirašineti: eismontasv@yahoo.com

Gauta 2021-09-29 